\title{
Pendidikan Agama Hindu Sebagai Dasar Dalam Pembentukan Karakter
}

\author{
Ni Wayan Ramini Santika \\ Institut Agama Hindu Negeri Tampung Penyang Palangka Raya \\ santikaramini@gmail.com
}

\begin{abstract}
Riwayat Jurnal
Artikel diterima: 20 Juli 2018

Artikel direvisi: 25 Oktober 2018

Artikel disetujui: 5 November 2018

\begin{tabular}{l|l}
\hline Kata Kunci: & Abstrak
\end{tabular}

Pendidikan Agama Hindu

Pembentukan Karakter

Kemajuan IPTEK cenderung menimbulkan perbedaan pandangan antara generasi tua dan generasi muda. Oleh karena itu mempelajari orientasi nilai pada kalangan remaja dan peserta didik, khususnya sikap keberagamannya tentulah penting dilakukan. Pembinaan generasi muda sebagai generasi penerus adalah tanggung jawab bersama antara keluarga, masyarakat bangsa dan negara. Dengan Pendidikan Agama Hindu dapat menjalankan dan mengamalkan ajaran Agama Hindu sehingga terbentuknya budhi pekerti yang luhur dan berakhlak yang mulia. Individu yang memiliki karakter mulia yaitu individu yang memiliki potensi diri seperti yang ditandai dengan nilai-nilai seperti percaya diri, rasional, logis, kreatif dan inovatif, mandiri, bertanggung jawab, sabar, rela berkorban, berpikir positif, disiplin, bersemangat, dinamis, produktif. Di dalam kitab suci Bhagavadgita dinyatakan ada dua kecendrungan yang mempengaruhi karakter manusia, yaitu sifat-sifat ke-devata-an (daivi sampat) dan sifat-sifat keraksasaan (asuri sampat). Kedua kecendrungan ini secara langsung atau pun tidak langsung akan membentuk karakter manusia.

Keyword:

Hiduism Education Character Building

\section{Abstract}

The progress of science and technology tends to give rise to differences between the older generation and the younger generation. Therefore learn the value orientation among young people and learners, especially the attitude of diversity is certainly important. Coaching youth as the next generation is a shared responsibility between families, communities and the nation state. With the Hindu, Religious Education can run and practice the teachings of Hinduism so that the formation budhi noble character and noble morals. Individuals who have a noble character is an individual who has potential as indicated by
\end{abstract}


values such as self-confident, rational, logical, creative and innovative, independent, responsible, patient, self-sacrificing, positive thinking, discipline, vibrant, dynamic, productive. In the holy book, Bhagavadgita stated two trends affect the human character, the properties of all devata's (daivi sampat) and properties of giant (asuri sampat). Both of these trends are directly or indirectly will shape human character.

\section{Pendahuluan}

Kehidupan pada masa modernisasi ini begitu banyaknya perubahan sosial yang pesat terjadi pada masyarakat dewasa ini ternyata membawa kecenderungan menimbulkan konflik nilai-nilai kehidupan sosial dan budaya, terutama sekali pada generasi muda pada kalangan remaja, dimana terjadi benturan nilai-nilai agama, tradisi dan adat dengan pesatnya. Kemajuan IPTEK cenderung menimbulkan perbedaan pandangan antara generasi tua dan generasi muda. Oleh karena itu mempelajari orientasi nilai pada kalangan remaja dan peserta didik, khususnya sikap keberagamannya tentulah penting dilakukan. Pembinaan generasi muda sebagai generasi penerus adalah tanggung jawab bersama antara keluarga, masyarakat bangsa dan negara. Berbagai upaya telah dilakukan dalam rangka pembinaan remaja baik di lingkungan keluarga maupun dalam masyarakat.

Dalam Undang - Undang Nomor 20 tahun 2003 tentang Pendidikan Nasional dalam pertimbangannya menyatakan bahwa Undang - Undang Dasar Negara Republik Indonesia tahun 1945 mengamatkan pemerintah mengusahakan dan menyelenggarakan suatu sistem pendidikan Nasional yang meningkatkan keimanan dan ketakwaan kepada Tuhan Yang Maha Esa serta ahklak mulia dalam rangka mencerdaskan kehidupan bangsa yang diatur dengan Undang - undang bahwa Sistem Pendidikan Nasional harus mampu menjamin kesempatan pendidikan, peningkatan mutu, serta relevansi dengan efesiensi manajemen pendidikan untuk menghadapi tantangan sesuai dengan tuntutan perubahan pendidikan secara terencana, terarah dan berkesinambungan. Sistem pendidikan nasional adalah keseluruhan komponen yang saling terkait dan terpadu untuk mencapai tujuan pendidikan nasional. Pendidikan nasional adalah pendidikan yang berdasarkan Pancasila dan Undang - undang Dasar tahun 1945, yang berakar pada nilai - nilai agama, Kebudayaan Nasional dan tanggap terhadap tuntutan jaman (Sisdiknas, 2003, hal. 1-2). Perlunya Pendidikan Karakter, secara imperatif tertuang dalam Undang - undang Nomor 20 Tahun 2003 tentang Sistem Pendidikan. Dalam Pasal 3 UU tersebut dinyatakan bahwa "Pendidikan Nasional berfungsi mengembangkan kemampuan dan membentuk watak serta peradaban bangsa yang bermartabat dalam rangka mencerdaskan kehidupan bangsa, bertujuan untuk berkembangnya potensi peserta didik agar menjadi 
manusia yang beriman dan bertakwa kepada Tuhan Yang Maha Esa, berakhlak mulia, sehat, berilmu, cakap, kreatif, mandiri, dan menjadi warga negara yang demokratis serta bertanggung jawab (Sisdiknas, 2003, hal. 6).

Individu yang memiliki karakter mulia yaitu individu yang memiliki potensi diri seperti yang ditandai dengan nilai-nilai seperti percaya diri, rasional, logis, kreatif dan inovatif, mandiri, bertanggung jawab, sabar, rela berkorban, berpikir positif, disiplin, bersemangat, dinamis, produktif. Individu tersebut juga memiliki kesadaran untuk berbuat yang terbaik atau unggul, dan individu juga mampu bertindak sesuai potensi dan kesadarannya tersebut. Karakteristik adalah realisasi perkembangan positif sebagai individu (intelektual, emosional, sosial, etika, dan perilaku). Kecakapan hidup tersebut dapat ditanamkan dengan melaksanakan pendidikan agama yang menekankan pada pembentukkan karakter, pendidikan agama merupakan salah satu aspek yang perlu mendapatkan perhatian khusus, karena melalui pendidikan agama sebagai dasar nantinya akan dapat membentuk pribadi manusia berbudi pekerti yang luhur dapat mengendalikan diri di tengah-tengah arus modernisasi ini.

\section{Pembahasan}

\section{Pendidikan Agama Hindu}

Pendidikan Agama Hindu merupakan suatu pendidikan yang sangat penting, Pendidikan Agama Hindu ini bertujuan memberikan pengajaran mental dan Spiritual bagi si anak. Pendidikan Agama Hindu telah diajarkan pada setiap sektor pendidikan, dimulai dari tingkat dasar sampai pada tingkat perguruan tinggi . Sesuai dengan UUD 1945 pada pasal 29 ayat 1 dan 2 serta Pancasila sebagai dasar falsafah bangsa Indonesia, maka pendidikan agama merupakan segi pendidikan yang utama yang menjadi dasar semua segi pendidikan lainnya. Pendidikan Agama Hindu diberikan pada peserta didik diharapkan agar menjadi orang yang bertaqwa kepada Tuhan Yang Maha Esa. Dengan Pendidikan Agama Hindu dapat menjalankan dan mengamalkan ajaran Agama Hindu sehingga terbentuknya budhi pekerti yang luhur dan berakhlak yang mulia, sebagaimana yang dinyatakan dalam Sarasamuscaya yang menyatakan sebagai berikut :

Apan iking dadi wwang, uttama juga ya nimitaning mangkana, wenang ya tumulang awaknya sangkeng sangsara, makasadhanang subhakarma, hinganing kottamaning dadi wwang ika.

(Sarasamuscaya, 4)

Artinya: 
Menjelma menjadi manusia itu adalah sungguh-sungguh utama, sebabnya demikian, karena ia dapat menolong dirinya dari keadaan sengsara (lahir dan mati berulang-ulang) dengan jalan berbuat baik, demikianlah keuntungannya dapat menjelma menjadi manusia.

(Kadjeng, 2010, hal. 9)

Dari kutipan Sarasamuscaya di atas, bahwa kehidupan itu sebagai proses pendidikan yang mana untuk memperbaiki diri sehingga tercapainya kesempurnaan hidup yang disebut "Moksartham Jagadhita ya ca iti Dharma".

Kegiatan pendidikan di dalam agama Hindu, dikenal dengan istilah "aguron-guron", atau "asewakadharma". Pengertian pendidikan dalam agama Hindu, tidak akan terlepas dari kedudukan kitab Veda sebagai sumber ajaran agama Hindu. Oleh karena itu kitab Veda dan susastra Hindu lainnya berfungsi sebagai pedoman yang menuntun manusia dalam menjalankan kegiatan sehari-hari, termasuk dalam kegiatan pendidikan.

Dalam meningkatan kualitas Sumber Daya Manusia Hindu pendidikan sudah dapat diperoleh melalui pendidikan informal dalam keluarga, pendidikan formal mulai dari tingkat PAUD, TK, SD, SMP, SMA hingga Perguruan Tinggi yang diperoleh di sekolah serta pendidikan nonformal salah satu contohnya Pasraman yang merupakan sekolah bernuansa Hindu lebih mendalami memberikan pengetahuan Agama Hindu.

Ilmu pengetahuan dapat menyeberangkan seseorang dari berbagai kesulitan hidup. Selain itu dengan pengetahuan seseorang dapat mempersembahkan sesuatu yang lebih tinggi nilainya, sebagaimana dalam Bhagavadgita IV.33 mengatakan:

śreyān dravya-mayad yajñāj

jñāna-yajñah paramtapa, sarvai் karmākhilam pārtha jūāne parisamāpyate.

(Bhagavadgita IV.33)

Artinya:

Persembahan berupa ilmu pengetahuan, wahai Arjuna, lebih mulia dari pada persembahan materi, dalam keseluruhannya semua kerja ini akan mendapatkan apa yang diinginkan dalam ilmu pengetahuan, wahai Partha (Pudja, 2004, hal. 126).

Dengan Ilmu pengetahuan tersebut suatu persembahan lebih mulia serta dengan ilmu pengetahuan suatu pekerjaan akan mendapatkan hasil seperti apa yang diharapkan sesuai dengan kutipan Bhagavadgita IV.33 tersebut diatas. 
Melalui perahu ilmu pengetahuan lautan dosa akan mampu diseberangi sesuai dari kutipan Bhagavadgita IV.36 dibawah ini,

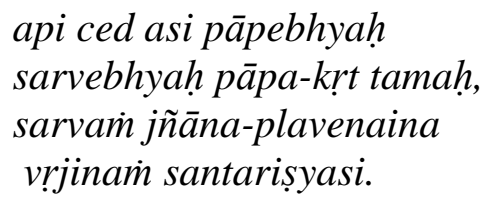

Artinya:

Walau seandainya engkau paling berdosa diantara manusia yang memikul dosa, dengan perahu ilmu pengetahuan ini, lautan dosa akan engkau seberangi (Pudja, 2004, hal. 127).

Dari kutipan kitab suci Bhagavadgita diatas sudah tentu ilmu pengetahuan merupakan jalan kita dalam meningkatan kualitas sumber daya manusia serta dapat membentuk Karakter menjadi lebih baik. Dengan memiliki ilmu pengetahuan yang mampu membakar segala karma menjadi abu sesuai dengan Bhagavadgita IV.37.

yathaidhämsi samiddho'gnir

bhasma-sāt kurute'rjuna,

jūānāgnih sarva-karmāni

bhasma-sāt kurute tathā.

(Bhagavadgita IV.37)

Artinya:

Bagaikan api menyala, wahai Arjuna yang membakar kayu api menjadi abu, demikian pula api ilmu pengetahuan membakar segala karma menjadi abu (Pudja, 2004, hal. 128).

Dengan ilmu pengetahuan kita mampu untuk menjalani kehidupan ini membayar (karmawasana) hasil dari karma yang pernah dialami daripada kehidupan yang lampau. Melalui pedang ilmu pengetahuan yang mampu memotong keraguan dalam hati serta ketidaktahuan, yang terkutip dalam Bhagawadgita IV.42.

$$
\begin{aligned}
& \text { tasmād ajñāna-sambhūtam } \\
& \text { hrt-stham jūānāsinātmanah, } \\
& \text { chittvainam samśayam yogam } \\
& \text { ātișthottiștha bhārata. }
\end{aligned}
$$

(Bhagavadgita.IV.42)

Artinya:

Oleh karena itu, setelah memotong keraguan dalam hatimu karena ketidaktahuan dengan pedangnya ilmu pengetahuan berpegang teguh pada yoga, bangkitlah, wahai Bharata (Pudja, 2004, hal. 131). 
Demikian pentingnya seseorang untuk memiliki ilmu pengetahuan sebagaimana uraian kitab suci Bhagavadgita di atas. Oleh sebab itu seorang "guru" ataupun dosen mutlak harus terus menerus menambah ilmu pengetahuan. Ilmu pengetahuan dapat membantu peningkatan kualitas intelektual. Intelektual yang tinggi menyebabkan perkembangan viveka, yaitu kemampuan membedakan antara yang baik dan yang buruk. Perkembangan viveka akan menajamkan kepekaan spiritual, yang juga berakibat pada berkembangnya kepribadian yang lebih mulia (Donder, 2008, hal. 198)).

Sejalan dengan tujuan agama adalah untuk mencapai "Jagadhita" dan "Moksa" yang dalam kalimat sanskerta sebagai berikut: "Atmano Moksartham Jagadhitaya ca” maka tujuan pendidikan Hindu pada hakikatnya sama dengan tujuan agama, yakni untuk mencapai "Jagadhita" (kesejahteraan dan kebahagian di dunia ini) dan "Moksa" (kebahagiaan abadi, bersatunya Atma dengan Brahma).

\section{Pendidikan Berdasarkan Tahapan Hidup Catur Asrama}

Tahapan hidup dalam Agama Hindu desebut dengan Catur Asrama yang terdiri dari Brahmacari, Grahasta, Wanaprasta dan Bhiksuka.

\section{Brahmacari}

Brahmacari adalah masa atau tingkat hidup dalam menekuni pencarian ilmu pengetahuan atau tingkat hidup berguru. Tingkatan hidup Brahmacari yang sering juga disebut dengan kehidupan aguron-guron atau aseweka guru adalah satu tingkatan kehidupan yang memerlukan ketekunan dan kesungguhan, karena dalam masa ini seorang Brahmacari akan menerima wejangan-wejangan dari guru sekaligus menghadapi ilmu pengetahuan yang memerlukan pemikiran yang sungguh-sungguh. Dalam Brahmacari seseorang akan dibentuk dan membentuk wataknya melalui pengembangan pengetahuan, ketrampilan, pemahaman, sikap, prilaku, serta nilai, guna memiliki pribadi yang utama berdasarkan dengan ajaran agama dan Dharma sehingga dapat berguna bagi dirinya sendiri dan juga orang lain.

\section{Grahasta}

Grahasta yakni tahapan hidup berumah tangga melalui perkawinan. Pada tahapan hidup ini mewujudkan Arta dan Kama adalah tujuan hidup yang paling mendapatkan prioritas utama. Arta dan Kama akan didapatkan dengan baik apabila didasari oleh Dharma. Adapun ciri dari seorang yang memasuki tahapan hidup Grahasta adalah memiliki kemauan untuk mandiri guna mewujudkan swadharmanya. Dalam Kakawin Nitisastra disebutkan ada lima kewajiban Grahasta yang disebut dengan Panca Wida yang terdiri dari: 1) Sang ametuaken, 
maksudnya adalah melahirkan keturunan; 2) Maweh bhinojana, yakni berusaha menjamin kebutuhan ekonomi keluarga; 3) Sang Mangupadyaya, memberikan pendidikan pada keluarga terutama pada anak baik moral, mental, dan ketrampilan atau keahlian guna menunjang profesi yang nantinya mampu mendukung dan menunjang kehidupannya; 4) Sang Anyangaskara, yaitu memberikan pendidikan kerokhanian, serta 5) Sang matulung urip ri kalaning bhaya, yaitu memberikan rasa aman dan melindungi dari mara bahaya. Berdasarkan Panca Wida itu maka dalam tahapan hidup Grahasta membina kesejahteraan keluarga adalah yang utama.

\section{Wanaprasta}

Wanaprasta, tahapan ini adalah tahapan hidup memasuki masa pensiun dan tahapan hidup mengurangi sedikit demi sedikit dari kesibukan duniawi. Saat Wanaprasta adalah saat terbaik untuk berbagi pengalaman hidup serta memberi petuah-petuah yang berguna bagi generasi muda atau generasi penerus, terutama yang masih berada pada tahap Brahmacari dan Grahasta. Seseorang yang memasuki tahapan hidup Wanaprasta akan mulai mengurangi melibatkan dirinya dari kehidupan kemasyarakatan. Hal ini berarti pula bahwa Artha dan Kama tidak begitu penting lagi sebagai sebuah tujuan. Untuk memasuki tahapan hidup ini sudah barang tentu diperlukan kesiapan yang matang yang artinya segala kewajiban pada tahapan sebelumnya telah terlaksanakan dengan baik. Pada masa ini yang terbaik dilakukan adalah melatih diri untuk melakukan tapa brata atau Samadhi.

\section{Bhiksuka}

Bhiksuka adalah tahapan hidup yang lebih memfokuskan diri pada persiapan penyerahan diri sepenuhnya pada Hyang Widhi. Pada masa ini selain melepaskan diri dari ikatan duniawai juga harus dapat melepaskan diri dari ikatan indrawi mengingat fungsi dari badan perlahan-lahan akan semakin berkurang dan harus diikhlaskan untuk dilepaskan. Kenyataan inilah yang mengharuskan seorang Bhiksuka mampu melepaskan ikatan Artha dan Kama dan memfokuskan diri pada spiritual guna bersiap melepaskan diri dari kehidupan di dunia ini. Jadi yang terpenting dari Bhiksuka adalah pelepasan diri dari duniawi dan indrawi (Sanjaya, 2011, hal. 63-66).

\section{Pendidikan Karakter}

Karakter menurut Pusat Bahasa Kementrian Pendidikan Nasional (Kemdiknas) mempunyai pengertian "bawaan, hati, jiwa, kepribadian, budi pekerti, perilaku, personalitas, sifat, tabiat, temperamen, watak". Sedangkan pengertian berkarakter adalah berkepribadian, 
berperilaku, bersifat, bertabiat, dan berwatak". Dalam pengertian lain, karakter mengacu pada serangkaian sikap (attitudes), perilaku (behaviors), motivasi (motivations), dan keterampilan (skills). Kata "karakter" berasal dari bahasa Yunani yang berarti "to mark" atau menandai dan memfokuskan pada bagaimana mengaplikasikan nilai kebaikan dalam bentuk tindakan atau tingkah laku, sehingga orang yang tidak jujur, kejam, rakus dan perilaku jelek lainnya dikatakan orang berkarakter jelek. Sebaliknya, orang yang perilakunya sesuai dengan kaidah moral disebut dengan berkarakter mulia.

Individu yang memiliki karakter mulia yaitu individu yang memiliki potensi diri seperti yang ditandai dengan nilai-nilai seperti percaya diri, rasional, logis, kreatif dan inovatif, mandiri, bertanggung jawab, sabar, rela berkorban, berpikir positif, disiplin, bersemangat, dinamis, produktif. Individu tersebut juga memiliki kesadaran untuk berbuat yang terbaik atau unggul, dan individu juga mampu bertindak sesuai potensi dan kesadarannya tersebut. Karakteristik adalah realisasi perkembangan positif sebagai individu (intelektual, emosional, sosial, etika, dan perilaku).

Individu yang berkarakter baik akan selalu berusaha melakukan hal-hal yang terbaik terhadap Tuhan Yang Maha Esa, dirinya, sesama, lingkungan, bangsa dan negara serta dunia internasional pada umumnya dengan mengoptimalkan potensi (pengetahuan) dirinya dan disertai dengan kesadaran, emosi dan motivasinya (perasaannya).

Menurut T. Ramli (2003), pendidikan karakter memiliki esensi dan makna yang sama dengan pendidikan moral dan pendidikan akhlak. Tujuannya adalah membentuk pribadi anak supaya menjadi manusia yang baik, baik di lingkungan keluarga, masyarakat dan bangsa serta dalam kehidupan bernegara. Oleh karena itu, hakikat dari pendidikan karakter dalam konteks pendidikan di Indonesia adalah pendidikan nilai-nilai luhur yang bersumber dari budaya bangsa Indonesia sendiri, dalam rangka membina kepribadian generasi muda (Kulsum, 2011, hal. 1-3).

\section{Karakter Manusia}

Svami Vivekananda mengatakan bahwa manusia ada empat macam. Yoga yang sejati, yoga yang ideal haruslah mampu memenuhi kecendrungan keempat jenis manusia ini. Karena dalam masyarakat kita terdapat berbagai sifat yang berbeda, maka ada ribuan jenis pikiran dan kecendrungan yang berbeda. 1) Manusia yang aktif atau pekerja, orang yang aktif ini akan sangat cocok menekuni karma yoga; 2) Orang yang emosional yang akan cocok menekuni bhakti yoga; 3) Orang yang berkecendrungan mistik, bergelut dengan cara kerja pikiran, yang tepat jika diantar menuju raja yoga; 4) Orang yang intelek melalui jnani yoga. 
Namun Shri Svami Vivekananda tidak mengkultuskan satu jalan dan meremehkan jalan lain. Beliau bahkan mengatakan, "Tentu saja manusia yang ideal adalah manusia yang memiliki keempat kecenderungan itu". Dan oleh karena demikian, maka keempat jenis yoga harus diperhatikan, dan satu akan menuntun pada yang lainnya. Keempat jenis yoga tersebut yaitu :

\section{Yoga untuk orang yang emosional dan penuh cinta adalah Bhakti Yoga}

Shri Svami Sivananda mengatakan "Istilah Bhakti datang dari akar kata Bhaj yang berarti "terhubungkan dengan Tuhan" Bhakti menjadi wujud cinta tertinggi ke arah Tuhan. Seorang pemuja hanya menginginkan Tuhan dan Tuhan saja. Tidak ada harapan egois di sini. Bhakti sifat alami manusia. Cinta tersebut begitu murni dan tak egois atau Suddha Prem. Cinta itulah suatu emosi tertinggi yang menghubungkan manusia dengan Tuhan.

\section{Yoga untuk seorang yang aktif adalah Karma Yoga}

Svami Vivekananda menjelaskan karma yoga sebagai berikut, "karma yoga mengajari kita cara bekerja demi pekerjaan itu sendiri, tanpa ikatan, tanpa memperdulikan siapa yang dibantu, dan tanpa berpikir tentang alasan melakukan pekerjaan itu sendiri. Posisinya di dalam dunia adalah sebagai pemberi, dan ia tidak peduli jika tidak pernah menerima sesuatu. Karena tidak terikat, ia tidak merasakan penderitaan dan rasa sakit”.

\section{Yoga untuk seorang mistis adalah Raja Yoga.}

Svami Vivekananda mengatakan bahwa Raja Yoga adalah Yoga Psikologi, yaitu bersatu dengan Tuhan melalui metode psikologis, dengan menyampaikan intisari dari yoga ini, yaitu konsentrasi. Makin besar konsentrasi, makin banyak pengetahuan yang diperoleh.

\section{Yoga untuk orang yang filosofis dan logis adalah Jnana Yoga.}

Dalam Bhagavad Gita, Jnana Yoga adalah sebuah cara menyatukan diri dengan Tuhan melalui Intelektualitas, rasionalitas dan logika. Pengetahuan sejati datang dari penguasaan diri, pengendalian diri, keyakinan dan bhakti. Hal ini membuktikan, seperti kata Gita, bahwa jnana adalah hasil. Hasil yang didapat baik dari karma yoga, bhakti yoga, dan raja yoga. Oleh karena itu, maka praktek dari yoga lain akan mengantar pada Jnana (Yudiantara, 2009, hal. 39-49).

Di dalam kitab suci Bhagavadgita dinyatakan ada dua kecendrungan yang mempengaruhi karakter manusia, yaitu sifat-sifat ke-devata-an (daivi sampat) dan sifat-sifat keraksasaan (asuri sampat). Kedua kecendrungan ini secara langsung atau pun tidak langsung akan membentuk karakter manusia. Bila seseorang kecendrungan 'daivi sampat'nya yang 
menonjol, maka orang tersebut senantiasa akan berbuat baik, namun bila kecendrungan 'asuri sampat'nya, maka ia akan menunjukkan sifat-sifat dan perilakunya yang buruk. Tentang dua kecendrungan ini, Sri Krsna di dalam Kitab suci Bhagavadgita menyatakan:

tejah kṣama dhṛtih śaucam

adroho nā 'timānitā,

bhavanti sampadai் daivim

abhijātasya bhārata.

Bhagavadgita XVI.3

Artinya

Cekatan, suka memaafkan, teguh iman, budi luhur, tidak iri hati, tanpa keangkuhan, semua ini adalah harta, dari dia yang dilahirkan dengan sifat-sifat devata, wahai Arjuna (Pudja, 2004, hal. 372).

dambho darpo 'bhimānaś ca

krodhah pārusyam eva ca,

ajñānam cābhijātasya

pārtha sampadam āsurim.

Bhagavadgita XVI.4

Artinya

Berpura-pura, angkuh, membanggakan diri, marah, kasar, bodoh, semuanya ini adalah keadaan mereka yang dilahirkan dengan sifat-sifat raksasa, wahai Partha (Arjuna) (Pudja, 2004, hal. 373).

Karakter negatif umat manusia bisa diperbaiki dengan berbagai cara di antaranya melatih seseorang untuk selalu berbuat baik (Titib, 2004, hal. 44-45).

\section{Simpulan}

Dalam pembahasan Pendidikan Agama Hindu sebagai dasar pembentukan karakter diatas dapat disimpulkan sebagai berikut ; Ilmu pengetahuan dapat membantu peningkatan kualitas intelektual. Intelektual yang tinggi menyebabkan perkembangan viveka, yaitu kemampuan membedakan antara yang baik dan yang buruk. Perkembangan viveka akan menajamkan kepekaan spiritual, yang juga berakibat pada berkembangnya kepribadian yang lebih mulia.

Kegiatan pendidikan di dalam agama Hindu, dikenal dengan istilah "aguron-guron", atau "asewakadharma". Pengertian pendidikan dalam agama Hindu, tidak akan terlepas dari kedudukan kitab Veda sebagai sumber ajaran agama Hindu. Sejalan dengan tujuan agama adalah untuk mencapai "Jagadhita" dan "Moksa" yang dalam kalimat sanskerta sebagai 
berikut: "Atmano Moksartham Jagadhitaya ca" maka tujuan pendidikan Hindu pada hakikatnya sama dengan tujuan agama, yakni untuk mencapai "Jagadhita" (kesejahteraan dan kebahagian di dunia ini) dan "Moksa" (kebahagiaan abadi, bersatunya Atma dengan Brahma). Di dalam kitab suci Bhagavadgita dinyatakan ada dua kecendrungan yang mempengaruhi karakter manusia, yaitu sifat-sifat ke-devata-an (daivi sampat) dan sifat-sifat keraksasaan (asuri sampat). Kedua kecendrungan ini secara langsung atau pun tidak langsung akan membentuk karakter manusia.

\section{Daftar Pustaka}

Donder, I. K. (2008). Acarya Sista : Guru atau Dosen yang Bijaksana Perspektif Hindu. Surabaya: Paramita.

Kajeng, I. N. (2010). Sarasamuccaya. Surabaya: Paramita.

Kulsum, U. (2011). Implementasi Pendidikan Karakter Berbasis Paikem. Surabaya: Gema Pratama Pustaka.

Pudja, G. (2004). Bhagawad Gita. Surabaya: Paramita.

Sanjaya, P. (2011). Filsafat Pendidikan Agama Hindu. Surabaya: Paramita.

Sisdiknas. (2003). Undang Undang Republik Indonesia No. 20 Tahun 2003 Tentang Sistem Pendidikan Nasional. Jakarta: Departemen Pendidikan Nasional.

Titib, I. M. (2004). Keutamaan Manusia Dan Pendidikan Budhi Pekert. Surabaya: Paramita. Yudiantara, I. P. (2009). Cerdas Spiritual Melalui Bhagavad Gita. Surabaya: Paramita. 